\title{
Research on the Quality Management System of Postgraduate Education in armed police academies Based on ISO9000 Standard
}

\author{
Zhang Jing \\ Logistics University of PAP, Tianjin, China, 300300 \\ 346591653@163.com
}

Keywords: ISO9000 standard, Armed police academies.; Postgraduate education quality management

\begin{abstract}
The postgraduate education of armed police academies is relevant to the building of a high-level talent team in Chinese People's Armed Police Force. And the education quality is the "lifeline" of the education in Armed police academies.. How to increase the education quality is a critical problem for the educator in Armed police academies.. This paper analysis the feature of ISO9000 quality standard system and construct the education quality management system of the postgraduate in the Armed police academies. based on ISO9000 by introducting the ISO9000 concept and related idea and thoughts, providing a certain reference significance for making the education quality management of the postgraduate more scientific and more normalized.
\end{abstract}

\section{Introduction}

The postgraduate education and training of the Chinese People's Armed Police Force(PAP), is not simply a process to teach the basic knowledge and science, but also a way to cultivate advanced science, technic, management and other aspects of the excellent talents for the armed police force. The quality of education is the "lifeline" of the postgraduate education institutions, which is directly related to build a solid foundation of a high-level personnel and a direct impact on the construction and development of PAP's modernization. However, the current postgraduate education quality management system of Armed police academies. is still not perfect, and it can not fully meet the current demand for high-level quality military personnel. How to improve the overall quality of postgraduate of the Armed police academies. is currently an urgent subject which is placed in the educators at all levels of PAP. And learn from the cultivate methods of the postgraduate quality education, we can consider bringing ISO9000 quality management system into Armed police academies., and establishment a comprehensive, scientific, formal postgraduate education quality management system.

\section{The main features of ISO9000 standard}

ISO is the abbreviation of "International Organization for Standardization", which was born in the 1940s. And ISO9000 is just a set of quality management and quality assurance standards issued by the organization in general. And its first edition, which was formally promulgated in 1987, is used by the world's nearly 200 countries or regions after being repeatedly modified and improved.ISO9000 quality management standards has become more and more important and plays an important role for various of fields. By analysising of the main features of ISO9000, we can provide a theoretical basis and reference for the establishment of the armed police academies' postgraduate education quality management system.

Strong commonality, wide range used. ISO9000 standard has a very wide range of content and it was widely used by various of firms, it provide a common theoretical basis and the standard mode for quality management of all walks of life. Especially 2000 edition of the ISO9000 quality management standards. It not only cleared the content of "cuts are allowed", but also considered the 
particularity of small enterprise, thus it made the oriented object and scope of this quality standard system more extensive, and enhanced the applicability and universality of the standard.

Stress the overall planning and management role. ISO9000 quality management emphasizes that the management process should first do a good job planning, clear objectives and specific work plan of quality management, and make a wonderful top-level design. It also emphasized that we should make a good division of functions and powers and coordinate different departments of the unit well at the process of implementation. What's more, we should timely supervise and examine every link of the quality management, so that we can take the whole situation into account and plan accordingly and ensure that the entire quality management system is in an orderly running.

Highlight the Continuous Improvement. ISO9000 emphasizes continuous improvement for the process of the quality management and correction for the constantly exposed problems. We should also propose corrective measures and programs to eliminate the influence of factors that prevent quality-improvement and re-emergence of substandard products. Thereby we can reduce the running cost of quality management. And the effectiveness of the quality management can be improved in circulation.

Advocate all staff involvement and recurrent training. ISO9000 advocates targeted recurrent training for different levels of staff and encouraging all employees to participate in the quality management system, thus the service awareness and professional competence of staff can be enhanced, so as to improve the overall quality of the management team through each individual of this system and make quality management permeate every aspect of the system.

Value the customer satisfaction and cultural management. In order to achieve customer satisfaction as the goal, ISO9000 emphasize the formation of corporate culture and enhancing the cohesion of the enterprise so as to form a centripetal force in improving the quality of products and service. Thereby the customers' confidence in the enterprise can be enhanced, and the customers' satisfaction with products and service can be improved. Finally, the competitiveness of the enterprise can be enhanced in the same market.

\section{Build the postgraduate education quality management system of armed police academies based on ISO9000 standards}

The core idea of ISO9000 standards embodies in its "eight principles of quality management", which runs through the whole process of quality management. And it is the soul of the entire management system. Therefore, the establishment of the postgraduate education quality management system of armed police academies should also be armed with these eight principles as a framework.

Customer focus. ISO9000 states, "Organizations depend on their customers and therefore should understand current and future needs, should meet customer requirements and strive to exceed customer expectations." The customers which are educated by armed police colleges graduate consist of two levels: The first is direct customers, referring to the postgraduate students who accept postgraduate education; The second is indirect customers, referring to the postgraduate students' parents, school feeding units, future employers and the armed police force. For direct customers, outstanding faculty, high-quality teaching, scientific management, strong academic atmosphere and a good learning environment for scientific research should be provided, in order to meet their academic research pursuits. For indirect customers, their satisfaction with the overall quality management system mainly reflect from their comprehensive ability and quality level when they graduate from the school, so we should set up professional counterparts and training programs not only according to indirect customers' different professions and different demand, but also combined with armed police academies' own characteristics.

Leadership. ISO9000 standards also said: "Leaders establish unity of purpose and direction of the organization. They should create and maintain the internal environment in which people can become fully involved in achieving the organization's objectives." The senior management of postgraduate quality management system should formulate quality guideline and policy based on direct and indirect customers needs and armed police colleges' own characteristics. They should 
also make good top-level design, set up scientific and rational organizations and create a harmonious internal environment and effective incentive mechanism to optimize the allocation of resources in postgraduate education, continuous measurement and improve the quality management system, so as to promote the realization of the quality policy and objectives.

Involvement of people. ISO9000 standards emphasize that people at all levels are the essence of an organization and their full involvement enables their abilities to be used for the organization's benefit. Graduate education management requires not only the attention of senior management, but also the needs of all members' active participation, including leaders, the faculty who participate in postgraduate education, postgraduate students and their parents, the units which send them to learn and employing units of PAP. We should fully mobilize active participation of all members and develop their awareness of education services. We should also promote volunteerism among people, mutual cooperation between the organization, and to play a role in the integration of different sectors, in order to make the quality management system more efficient and orderly operate .

Process Approach. ISO9000 standard states: " A desired result is achieved more efficiently when activities and related resources are managed as a process." Wherein the ISO9000: 2000 edition also proposed a "process model" concept, including management responsibility, resource management, service implementation, measurement, analysis and improvement through PDCA cycle (plan-disposal-check-action) in order to evaluate the entire system. The postgraduate education of armed police academies is also a kind of education service and management with a series of contents, including recruiting students, selecting instructors, teaching programs, scholarly researching, the mid-screened, open discussion, practicing in PAP, investigate and survey, research papers published, graduation defense, degree-granting process and so on. In order to protect the entire system level of quality, it is necessary to control each process aspects effectively.

Systems approach to management. ISO9000 standards emphasize: "Identifying, understanding and managing interrelated processes as a system contributes to the organization's effectiveness and efficiency in achieving its objectives." This requires identifying every process of the armed police academies' postgraduate education which was involved in the above-mentioned. By analyzing various interrelated processes, which as a whole to systematically manage and control, we can promote the efficient operation of quality system.

Continual improvement. ISO9000 standard states that continual improvement of the organization's overall performance should be a permanent objective of the organization." To achieve continual improvement of the quality of armed police academies' postgraduate education, it is necessary to correct the problems of every link in the process of quality management timely in accordance with the established quality policy and objectives and combine with the actual situation of armed police academies. WE should also constantly sum up experience, propose corrective measures, drawing on valuable theory and method to make it continuously improved and enhanced.

Factual approach to decision making. ISO9000 standard proposes that effective decisions are based on the analysis of data and information. To get real and effective data and information, it is necessary to research in the grassroots units and academies of PAP deeply and fully understand the needs of the PAP personnel and armed police academies' own characteristics. Scientific analysis of data and information with qualitative analysis and quantitative analysis method is also needed. Furthermore, we should also collect, collate and analyze various types of information and data which are involved in the process of education quality management regularly at any time, such as the number of papers published, curriculum assessment results, the mid-screening results, teaching feedback tables and so on. Managers should make appropriate decisions and take timely measures based on these real and effective data.

Mutually beneficial supplier relationships. ISO9000 also stressed: " An organization and its suppliers are interdependent and a mutually beneficial relationship enhances the ability of both to create value." Promoting collaborative development between the organization and the supplier and achieving mutual benefit is the best way to develop the system. Postgraduate education in armed police colleges are interdependent with graduate students and their parents, school feeding units, future employers and even the PAP corps. The implement of postgraduate education management in 
armed police colleges should effectively grasp the long-term interests and short-term interests, the overall interests and local interests, and find a balance between the various stakeholders in each other, in order to achieve mutual benefit and common development with graduate students and their parents, employers and the PAP corps.

\section{References}

[1] Augustus E. Osseo-Asare, David Longhottom, Pieris Chourides. Managerial leadership for total quality improvement in UK higher edueation[J]. Technical report, The TQM Magazine, 2007, Vol.19

[2] Gitaehari Srikanthan, John F. Dalrymple. A conceptual overview of a holistic Model for quality in higher edueation[J]. The International Journal of Educational Management, 2007, Vol.21

[3] Ahmed A. Bin-Muburak. Should Higher Education Institutions Use IS09001 Model to Achieve Academic Excellence[R]. Netherlands: Maastricht School of Management, 2011.

[4] Nina Becket, Maureen Brookes. Quality Management Practice in Higher Education [J]. Journal of Hospitality, Leisure, Sport \& Tourism Education, 2008, 7 (01) : 40-54. 